\title{
Influence of Local Wisdom-Based Blended Learning Module for Environmental Geography Towards Problem-Solving Skill
}

\author{
Sumarmi \\ Department of Geography, Faculty of Social Science \\ Universitas Negeri Malang \\ Malang, Indonesia \\ sumarmi.fis@um.ac.id
}

\begin{abstract}
The module aims at guiding and directing activities in a learning process as well as helping students in learning and mastering certain competencies. In addition, the module is also a type of assessment tool to evaluate learning achievement. The purpose of the study was to find out the influence of local wisdom-based blended learning module for environmental geography class on problem-solving skill. The study was a quasiexperiment design with pre-test and post-test group design. It was conducted in the even semester of 2016-2017 academic year. The research subjects were undergraduate students of the Geography Department of State University of Malang, particularly $L$ and $K$ groups of batch 2014. Class $K$ was the experimental group consisting of 27 students while class $L$ was the control group consisting of 28 students. The data were analyzed using t-test. Based on the $t$-test, the $t$-statistics was 3.303 with probability $(\mathrm{sig})=\mathbf{0 . 0 0 1}$. The average score of the experimental group was $\mathbf{9 . 0 4 4 4}$, which was higher than that of the control group (5.2381). In conclusion, the local wisdom-based blended learning module for environmental geography had a significant influence towards the problem-solving skill.
\end{abstract}

Keywords-module, blended learning, problem-solving skill

\section{INTRODUCTION}

The rapid growth of science, technology, information, and communication as well as more competitive business competition in the international level requires problem-solving skills. The learning process should prepare learners to acquire not only theoretical knowledge but also ability to actively overcome contextual issues they find on the daily basis. Therefore, learning materials should be contextual and allow students developing their problem-solving skills.

Contextual geography class, according to Maryani [1], should be oriented to: (1) actual and social issues students encounter in their daily lives, (2) psychological development of the students, (3) improvement of the student's welfare through introduction and utilization of resources, (4) the student's future by widening their global horizon introducing them to both challenge and opportunity. In the context of the study, social issues refer to environmental issues.

There are various types of environmental issues, for instance, pollution, flood, drought, land slide and global warming. As the consequence, the ability to solve these environmental issues is pivotal. To do so, geography class should enable students to develop their problem-solving skills by integrating the class and the local wisdom. The local wisdom-based blended learning module is necessary for geography class. Local wisdom refers to ideas, values as well as perspectives that locals consider full of wisdom and true. As the result, it is embedded and applied by the society. Local wisdom is local knowledge the society uses to survive in the certain environment, an element having integration with a belief system, norm, and culture and it is expressed in tradition and myth the society believes in for a long time [2]-[4]

Sharples and Spikol discussed how technology supports the blended learning to obtain effective communication during the learning process [5]. Communication may be conducted between places and topics. Yeop, Wong, and Noh's study elaborated the gap in blended learning method, and improved knowledge and skills related to the blended learning in Malaysia [6]. Furthermore, Thai, De Wever, and Valcke made a comparison between the effectiveness of Teaching Learning (TL) and that of Blended Learning (BL) [7].

The objective of the study is to describe the influence of local wisdom-based blended learning module for environmental geography towards problem-solving skill. The similarity of the study and three previous studies discussed earlier is focusing on blended learning. The difference between the previous studies and this study is focusing on student's understanding and ability on online communication while the latter emphasizes on the influence of local wisdom-based blended learning module towards problem-solving skill. The local wisdom-based blended learning module for environmental geography is equipped with pictures, video, power point slide, government regulations related to environmental issues, quiz and the others media. Blended learning is the selected learning method because it is a challenge to print out the module.

\section{METHOD}

The study had two types of variables (1) independent variable which is local wisdom-based blended learning module for environmental geography and (2) dependent variable which 
is problem-solving skill. The research design was a quasiexperiment with pre-test and post-test of control group design.

Both groups, experimental and control groups, were asked to take a pre-test to assess their preliminary competence. Both groups were given different treatments. The experimental group was taught using the local wisdom-based blended learning module for environmental geography while the control group was taught using conventional methods, lecture, discussion, and question-answer. Both groups were then asked to take a post-test to assess their competence after the treatments. Besides selecting two classes as the subjects, the researchers selected one more class for testing (group A) from the essay given to the experimental and control groups. Table 1 discussed the research design briefly.

The study was conducted in the even semester of 2016/2017 academic year. The subjects were undergraduate students of the Geography Department, Faculty of Social Science, the State University of Malang, particularly those belonged to group $\mathrm{K}$ and L of batch 2014. They were selected as the subjects because they were homogenous. Their average GPAs were similar. Group K consisted of 27 undergraduate students and became the experimental group, while group L consisted of 28 students becoming the control group.

The study evaluated different problem-solving skill between the experimental and control groups. In general, there were three types of treatment. The first treatment involved observation to identify the student's condition during the learning process, the number of students (subject), their time table and GPA. The following procedure was to decide the experimental and control groups. The second one was to conduct pre-test to evaluate the students' preliminary skills and then, give the treatment to both groups of students. The treatments were (1) the local wisdom-based blended learning module for environmental geography for the experimental group, and (2) conventional method (lecture, discussion, question-answer with power point slides as the media) for the control group. The third one was to conduct post-test to both groups to evaluate the students' skill after they have been given the treatments. Post-test scores were subtracted by pre-test scores to gain the score representing the students' ability in environmental geography. Based on the gained scores, the researchers described and analyzed the influence of the local wisdom-based blended learning module for environmental geography towards the student's problem-solving skill.s

Despite different treatments both groups got, they had the same meetings and lecturer. Both groups had 16 meetings in a semester and each meeting lasted for 100 minutes.

The instruments were pre-test and post-test to assess problem-solving skill. The type of test was 6-items essay asking students to analyze (C3) and to create (C6). Prior to administering the tests, they were given to group A to find out validity and reliability of the tests.
TABLE I. RESEARCH DESIGN

\begin{tabular}{|l|l|l|l|}
\hline \multicolumn{1}{|c|}{ Group } & Pre-test & Treatment & Post-Test \\
\hline Experiment $(\mathrm{E})$ & $\mathrm{O}_{1}$ & $\mathrm{X}$ & $\mathrm{O}_{2}$ \\
\hline Control $(\mathrm{K})$ & $\mathrm{O}_{1}$ & - & $\mathrm{O}_{2}$ \\
\hline
\end{tabular}

Source: Adapted from Arikunto [8]

Description:

$\mathrm{E}=$ Experiment class

$\mathrm{K}=$ Control class

$\mathrm{O}_{1}=$ preliminary assessment in the form of pre-test

$\mathrm{O}_{2}$ = final assessment in the form of post-test

$\mathrm{X}=$ treatment (local wisdom-based blended learning module)

- $\quad=$ conventional learning i.e. lecture, discussion, and question-answer

\section{RESULTS AND DISCUSSION}

\section{A. Pre-test and Post-test Scores of the Experimental and} Control Groups as the Indicators of Problem-Solving Skill

The data explaining the influence of the local wisdombased blended learning module for environmental geography towards problem-solving skill are as follow:

1) Pre-test Scores

The pre-test was a test given to the students before using the local wisdom-based blended learning module. Table 2 describes the pre-test scores of the experimental group.

Based on Table 2, the average pre-test score of the experimental group was 81.44 . The score fell into the fourth category (82-84). There were 12 students whose scores were within the category. Table 3 describes the distribution of the pre-test scores of control.

TABLE II. PRE-TEST SCORE DISTRIBUTION OF THE EXPERIMENTAL GROUP

\begin{tabular}{|c|c|c|c|}
\hline Range of Score & $\mathbf{F}$ & $\%$ & \multirow{8}{*}{ Mean $=81.44$} \\
\hline $91-93$ & 1 & 2.22 & \\
\hline $88-90$ & 5 & 11.11 & \\
\hline $85-87$ & 5 & 11.11 & \\
\hline $82-84$ & 12 & 26.67 & \\
\hline $79-81$ & 12 & 26.67 & \\
\hline $76-78$ & 3 & 6.67 & \\
\hline $73-75$ & 7 & 15.56 & \\
\hline Total & 45 & 100 & \\
\hline
\end{tabular}


TABLE III. PRE-TEST SCORE Distribution OF THE CONTROL GROUP

\begin{tabular}{|c|c|c|c|}
\hline Range of Score & $\mathbf{F}$ & $\%$ & \multirow{7}{*}{ Mean $=79.29$} \\
\hline $90-94$ & 3 & 7.14 & \\
\hline $85-89$ & 10 & 23.80 & \\
\hline $80-84$ & 13 & 30.95 & \\
\hline $75-79$ & 11 & 26.19 & \\
\hline $70-74$ & 4 & 9.52 & \\
\hline 65-69 & 1 & 2.38 & \\
\hline Total & 42 & 100 & \\
\hline
\end{tabular}

Based on Table 3, the average pre-test score of the control group was 79.29. The majority of students, 13 students, scored between 80 and 84, while 11 of them scored between 75 and 79. Based on the distribution, the average score of the experimental and control group was similar.

\section{2) Post-test Scores}

Post-test was administered to the students after the treatment. The purpose was to assess the student's problemsolving skill post treatment. Table 4 describes the post-test scores of the experimental group.

Based on Table 4, the average post-test score of the experimental group was 90.49 . The majority of students, 22 students, scored between 91 and 92 , while 12 of them scored between 89 and 90 . Next, Table 5 describes the post-test scores of the control group.

TABLE IV. POST-TEST SCORE DISTRIBUTION OF THE EXPERIMENTAL GROUP

\begin{tabular}{|c|c|c|c|}
\hline Range of Score & $\mathbf{F}$ & $\%$ & \multirow{8}{*}{ Mean $=90.49$} \\
\hline $97-98$ & 0 & 0 & \\
\hline $95-96$ & 0 & 0 & \\
\hline $93-94$ & 2 & 4.44 & \\
\hline $91-92$ & 22 & 48.89 & \\
\hline $89-90$ & 18 & 40.00 & \\
\hline $87-88$ & 2 & 4.44 & \\
\hline $85-86$ & 1 & 2.22 & \\
\hline Total & 45 & 100 & \\
\hline
\end{tabular}

TABLE V. Post-Test Score Distribution of the Control Group

\begin{tabular}{|c|c|c|c|}
\hline Range of Score & $\mathbf{F}$ & $\%$ & \multirow{7}{*}{ Mean $=84.52$} \\
\hline $93-96$ & 5 & 11.90 & \\
\hline $89-92$ & 6 & 14.28 & \\
\hline $85-88$ & 11 & 26.19 & \\
\hline $81-84$ & 6 & 14.28 & \\
\hline $77-80$ & 12 & 28.57 & \\
\hline $73-76$ & 2 & 4.76 & \\
\hline Total & 42 & 100 & \\
\hline
\end{tabular}

Based on Table 3, the average post-test score of the control group was 84.52 . The majority of students, 12 students, scored between 77 and 80 , while 11 of them scored between 85 and 88 .

\section{3) T-test}

Based on the data analysis using a t-test, the t-statistics was 3.303 with probability $(\mathrm{sig})=0.001$. The mean score of experimental group 9.0444, was higher than that of the control, which was 5.2381. Therefore, the local wisdom-based blended learning module for environmental geography was more effective in improving the problem-solving skill compared to the conventional methods (lecture, discussion, and questionanswer).

The finding was in line with that of Wardhani [9], stating that web-based learning was a really effective method. In conclusion, the module was an alternative learning strategy as it allowed students to develop their problem-solving skill independently.

The local wisdom-based blended learning module could help achieving the learning purpose effectively since the module was well-organized and equipped with online materials. The module was also time-efficient. The finding corroborated to Luik [10], mentioning that web-based learning helped both teachers and students achieve learning objectives and saved much time.

A previous study conducted by Nazarenko [11], towards blended learning for courses showed that the method allowed students to develop their professional competence and obtain more information. The finding of Herloa [12], explained that as the result of BL, $32 \%$ of the students obtained excellent grades, $52 \%$ got an optimum grade and $16 \%$ got a good grade. As an addition, Soler, Soler, and Araya [13], addressed that blended learning was a suitable strategy to increase the quality of education, access and learning process.

The advantages of blended learning are it is contextual, facilitates online learning (web-based learning) and caters different learning styles, learning atmosphere and assessment. The finding also showed that the highest score was in line with the classroom meeting. The conclusion stated that there was no any significant difference between achievement and student's learning style [14]. 
The students taught using the local wisdom-based blended learning module had higher problem-solving skill compared to those taught using conventional methods (lecture, discussion and question-answer). It was in line with the study of Mamentu [15] presenting that $78.5 \%$ of the students' learning quality was improved using e-learning materials. The improvement was affected by such indicators as web quality, delivery, program interaction, user interaction, instructions, and the design of learning and e-learning facilities.

According to Sandi, blended learning created effective and efficient learning as well as made it easier for teachers to evaluate every student's involving monitoring and finding solutions (problem-solving). Blended learning is more meaningful because the materials are designed in such a way so that the students understood the concepts more easily [16]. Blended learning may be implemented for both face-to-face learning as well as e-learning. The students could repeat or ask questions of any concepts they had not understood.

The study used Moodle, an application that was once used in Amiroh's study [17]. It revealed that Moodle is the most frequently used LMS in learning that combines face-to-face and e-learning. According to Dwiyogo [18], blended learning had at least 6 (six) elements, namely: (a) face-to-face meeting (b) independent study, (c) application, (d) tutorial, (e) cooperation, and (f) evaluation. Thorne [19], described blended learning as "It represents an opportunity to integrate the innovative and technological advances offered by online learning with the interaction and participation offered in the best traditional learning." The advantages of blended learning were it allows a wider range of learning/training, it is easy to apply, cost efficient, gives optimum learning outcome, meets different student's needs and makes the learning more enjoyable.

\section{CONCLUSION}

Based on the findings, it is concluded that local wisdombased blended learning module for environmental geography class is more effective in improving student's problem-solving skill than the conventional methods (lecture, discussion, and question-answer). This case is because the module consists of materials of high environmental ethics the society considers as the local wisdom. Besides, it contains contextual environmental issues, video, pictures and images that facilitate e-learning. As the result, students can learn anywhere, anytime using more various materials.

\section{REFERENCES}

[1] E. Maryani, "Kontribusi Pendidikan Geografi dalam Mengembangakan Modal Sosial untuk Menuju Keunggulan Berbangsa dan Bernegara," in National Seminar of Social Science in Indonesian University of Education, 2006.

[2] S. Sumintarsih, S. Salamun, S. Sukari, C. Ariani, and S. Sujarno, Kearifan Lokal Di Lingkungan Masyarakat Nelayan Madura. Jakarta: Kementrian Kebudayaan dan Pariwisata, 2005.

[3] S. Sartini, "Menggali Kearifan Lokal Nusantara: Sebuah Kajian Filsafati," J. Filsafat, vol. 14, no. 2, pp. 111--120, 2004.

[4] M. A. Marfai, Pengantar Etika Lingkungan dan Kerifan Lokal. Yogyakarta: Gadjah Mada University Press, 2012.

[5] M. Sharples and D. Spikol, "Mobile Learning," in Technology Enhanced Learning: Research Themes, E. Duval, M. Sharples, and R. Sutherland, Eds. Cham: Springer International Publishing, 2017, pp. 89-96.

[6] M. A. Yeop, K. T. Wong, and N. M. Noh, "Blended learning in selected journals: a content analysis using the Complex Adaptive Blended Learning Systems," Int. J. Instr. Technol. Distance Learn., vol. 13, no. 10, pp. 47-58, 2016.

[7] N. T. T. Thai, B. De Wever, and M. Valcke, "The impact of a flipped classroom design on learning performance in higher education: Looking for the best 'blend' of lectures and guiding questions with feedback,' Comput. Educ., vol. 107, pp. 113--126, 2017.

[8] S. Arikunto, Prosedur Penelitian suatu Pendekatan Praktik, Edisi VI. Jakarta: Rineka Cipta, 2006

[9] K. Wardhani, R. Sugiyanto, and A. B. Santoso, "Penerapan E-Learning Geografi Melalui Media Berbasis Web (Facebook)," J. Edu Geogr., vol. 1 , no. $1,2012$.

[10] P. Luik, "Web Based-Learning or Face-to-Face Teaching-Preferences of Estonian Students," 2006.

[11] A. L. Nazarenko, "Blended learning vs traditional learning: What works?(a case study research)," Procedia-Social Behav. Sci., vol. 200, pp. 77--82, 2015.

[12] D. Herloa, "Improving Efficiency of Learning in Education Master Programs, by Blended Learning," Procedia-Social Behav. Sci., vol. 191, pp. 1304--1309, 2015.

[13] R. Soler, J. R. Soler, and I. Araya, "Subjects in the Blended Learning Model Design. Theoretical-Methodological elements," Procedia - Soc. Behav. Sci., vol. 237, no. June 2016, pp. 771-777, 2017.

[14] B. Akkoyunlu and M. Yilmaz-Soylu, "A study of student's perceptions in a blended learning environment based on different learning styles,' Educ. Technol. Soc., vol. 11, no. 1, pp. 183--193, 2008.

[15] F. Y. Mamentu, "Pengaruh Penggunaan media Pembelajaran Online Edmodo Terhadap Hasil Belajar Siswa Kelas XI Pada Mata Pelajaran TIK Di SMAN 1 Tondano," J. Ilm. Eng. Educ., vol. 4, 1AD.

[16] G. Sandi, "Pengaruh Blended Learning terhadap Hasil Belajar Kimia ditinjau dari Kemandirian Siswa," J. Pendidik. dan Pengajaran, vol. 45 no. 3, p. 241-251, 2012.

[17] Amiroh, Kupas Tuntas Membangun E-Learning dengan Learning Management System Moodle 2.0. Sidoarjo: Genta Group Production, 2012.

[18] W. Dwiyogo, "Pembelajaran Penjas Berbasis Blended Learning," 2016.

[19] K. Thorne, Blended Learning: How to integrate online \& traditional learning. London: Kogan Page Publishers, 2003. 